\title{
PENGARUH MODEL PEMBELAJARAN BERBASIS MASALAH DAN KOOPERATIF THINK PAIR SHARE TERHADAP HASIL BELAJAR IPS
}

\section{THE EFFECT OF PROBLEM-BASED LEARNING MODEL AND COOPERATIVE LEARNING OF THINK PAIR SHARE}

\author{
Dina Anika Marhayani, Hastuti \\ Program Studi Pips, Konsentrasi PIPS Terpadu, UNY \\ dinaanika89@gmail.com, hastuti@uny.ac.id
}

\begin{abstract}
Abstrak
Penelitian ini bertujuan untuk membandingkan pengaruh model pembelajaran berbasis masalah dan kooperatif Think Pair Share terhadap hasil belajar IPS. Penelitian eksperimen ini menggunakan matched subjects designs. Penentuan sampel menggunakan teknik random sampling. Pengumpulan data menggunakan tes. Data diolah menggunakan analisis $T$ - test pada taraf signifikansi 0,05 . Hasil penelitian menunjukkan bahwa hasil belajar IPS antara peserta didik yang belajar menggunakan model pembelajaran berbasis masalah dengan nilai rerata sebesar 83, 19 lebih tinggi dibandingkan rerata dengan model kooperatif Think Pair Share 73, 88. Peningkatan hasil belajar antara peserta didik yang menggunakan model pembelajaran berbasis masalah dan kooperatif Think Pair Share diperoleh T hitung 15, $189>$ T tabel 2, 042 pada taraf signifikansi 0,05, artinya terdapat perbedaan pengaruh model pembelajaran berbasis masalah dan model Think Pair Share terhadap hasil belajar IPS.
\end{abstract}

Kata kunci: model pembelajaran, hasil belajar

\begin{abstract}
This research aims to compare the effect of problem-based learning model and cooperative learning model of Think Pair Share type on the learning achievement in social studies. This study was an experimental study using matched subjects designs. The sampel was using the random sampling technique. The data collection used a tes. The data were analyzed using T-test at the significance level of 0.05 . The result of this study shows that: the students who were taught using problem-based learning got mean score 83.19 higher than those taught using cooperative learning model of Think Pair Share with mean score 73.88. There is a different effect of problem-based learning model and cooperative learning model of Think Pair Share type on the learning achievement in social studie with T count 15.189 > T tabel 2.042 at the significant level of 0.05 .
\end{abstract}

Keywords: learning model, learning achievement 


\section{Pendahuluan}

Pendidikan diartikan sebagai upaya meningkatkan harkat dan martabat manusia serta dituntut untuk menghasilkan kualitas manusia yang lebih tinggi guna menjamin pelaksanaan dan kelangsungan pembangunan. Peningkatan kualitas manusia harus dipenuhi melalui peningkatan kualitas pendidikan yang meliputi tenaga kependidikan, peserta didik, dan pembaharuan kurikulum sesuai dengan perkembangan ilmu pengetahuan dan teknologi. Kini di era globalisasi, Indonesia masih menghadapi berbagai masalah internal cukup mendasar dan bersifat kompleks dalam bidang pendidikan. Indonesia menghadapi berbagai permasalahan, seperti peserta didik yang mendapat kesempatan belajar yang kurang merata, banyak peserta didik yang putus sekolah, dan tenaga terdidik yang menganggur cenderung terus meningkat. Indonesia menghadapi berbagai permasalahan, seperti peserta didik yang mendapat kesempatan belajar yang kurang merata, banyak peserta didik yang putus sekolah, dan tenaga terdidik yang menganggur cenderung terus meningkat.

Data dari United Nations Development Programme (2014), Indonesia berada pada peringkat 108 di dunia dari segi kualitas sumber daya manusia.

Indonesia menghadapi permasalahan begitu banyak, sehingga tugas berat bagi bangsa Indonesia adalah menyiapkan sumber daya manusia berkualitas, cerdas, kreatif, dan berdaya saing agar mampu bersaing pada tataran global. Kualitas sumber daya manusia dapat dihasilkan melalui penyelenggaraan pendidikan bermutu. Pendidikan yang bermutu harus mampu mengembangkan potensi peserta didik untuk memiliki ketrampilan dan kecakapan hidup yang diperlukan untuk dirinya dan masyarakat, hal ini sesuai dengan UndangUndang No. 14 Tahun 2005 tentang Guru dan Dosen menjelaskan bahwa pendidikan harus mampu membekali peserta didik dengan kecakapan hidup (life skill) sesuai dengan lingkungan kehidupan dan kebutuhan peserta didik. Pendidikan yang dibutuhkan peserta didik harus diarahkan pada usaha sadar guna menumbuhkan potensi guru sebagai sumber daya. Potensi guru dapat dikembangkan dengan cara menciptakan suasana pembelajaran yang menarik dan memilih model pembelajaran yang relevan pada proses pembelajaran.
Proses pembelajaran harus menyentuh tiga kompetensi yaitu kompetensi pengetahuan, sikap, dan keterampilan. Hasil akhir proses pembelajaran bertujuan agar peserta didik mempunyai keseimbangan antara kemampuan menjadi peserta didik yang taat kepada Tuhan juga memiliki ketrampilan yang baik dan pengetahuan yang cukup sehingga menjadi peserta didik berkualitas pada mata pelajaran ilmu pengetahuan sosial (IPS) sebagai mata pelajaran secara terpadu. Trianto $(2010$, p.171) menyatakan bahwa IPS merupakan integrasi dari berbagai cabang ilmu-ilmu sosial, seperti sosiologi, sejarah, geografi, ekonomi, politik, hukum, dan budaya. Ilmu Pengetahuan Sosial dirumuskan atas dasar realitas dan fenomena sosial yang diwujudkan satu pendekatan interdisipliner dari aspek dan cabang-cabang ilmu sosial. IPS merupakan bagian dari kurikulum sekolah yang diturunkan dari isi materi cabang-cabang ilmu sosial. Mata pelajaran IPS sebagai mata pelajaran terpadu mempunyai keterkaitan makna dan fungsi, yang apabila diramu ke dalam satu konteks tertentu seperti peristiwa, isu, masalah, atau tema dalam setiap pembelajaran, artinya pembelajaran IPS mengkaji tentang fenomena-fenomena yang terjadi di masyarakat baik masa lalu, masa sekarang, dan kecenderungannya pada masamasa mendatang.

Pembelajaran IPS yang diajarkan secara terpadu membuat guru mempunyai kemampuan untuk menciptakan lingkungan belajar yang menyenangkan, mengelola proses pembelajaran yang efektif, serta menumbuhkan peserta didik terutama dalam memecahkan masalah. Kebutuhan peserta didik untuk memecahkan masalah di masyarakat menjadikan pembelajaran IPS sebagai suatu proses pembelajaran yang sangat menarik, selain itu pembelajaran IPS bertujuan agar peserta didik mampu mengembangkan kompetensi kearah kehidupan bermasyarakat dengan baik dan memiliki kepekaan sosial, serta mempunyai ketrampilan dalam memecahkan masalah pada pembelajaran IPS. Pembelajaran IPS menurut Trianto, (2010, p.173) bertujuan mempersiapkan peserta didik menjadi warga negara yang berguna bagi masyarakat. Adanya pembelajara IPS diharapkan peserta didik memiliki kecerdasan dan keterampilan dalam berbagai hal yang terkait kehidupan sosial kemasyarakatan. Peserta didik dapat menghayati nilai-nilai hidup yang baik serta memiliki kesadaran dan 
kepedulian terhadap masyarakat dan lingkungan.

Proses pembelajaran IPS sesuai kenyataan dilapangan ditemui belum semua pembelajaran IPS menggunakan model pembelajaran yang bervariasi bagi peserta didik. Hasil survai yang diungkapkan Suparman sebagai koordinator education forum yang termuat pada surat kabar harian Republika tanggal 22 April 2015 bahwa masih banyak ditemukan model pembelajaran yang tidak inovatif karena guru kerap terbentur pada target penyelesaian muatan-muatan kurikulum, sehingga diperlukan pelatihan mengembangkan model pembelajaran bagi guru seperti pelatihan yang dilakukan oleh USAID PRIORITAS yang diikuti guru dari 10 sekolah dasar dan sekolah menegah di Daerah Istimewa Yogyakarta. Hasil survai juga dilakukan oleh Sekretaris Jendral Frederasi Serikat Guru Indonesia (FSGI) di 29 kabupaten/ kota di Jakarta sebagai ibukota negara masih ada guru yang belum mendapat pelatihan cara mengajar dengan menggunakan model pembelajaran yang bervariasi bagi peserta didik.

Permasalahan lain dalam proses pembelajaran yang muncul di sekolah adalah belum optimalnya hasil belajar yang diperoleh peserta didik. Adanya program remidial yang diselenggarakan di sekolah dapat menjadi tolak ukur utama masih kurangnya hasil belajar tersebut. Pengamatan yang diperoleh di SMP Negeri 2 Turi dan SMP N 3 Kalasan bahwa hasil belajar peserta didik yang belum optimal, dapat dilihat dari hasil ujian tengah semester 2013/2014 bahwa peserta didik belum mencapai KKM yang ditentukan oleh sekolah yakni 75 . Ada 22 peserta didik yang belum tuntas dari 32 jumlah peserta didik di SMP N 2 Turi dan 20 peserta didik yang belum tuntas dari 32 peserta didik di SMP N 3 Kalasan belum mencapai KKM, sehingga peserta didik yang kurang mencapai KKM dilakukan ujian ulang atau remidi. Peserta didik yang belum mencapai belajar tuntas maka proses pembelajaran IPS perlu diperbaiki agar hasil belajar peserta didik menjadi lebih optimal. Bukti tentang kurang optimalnya tingkat pencapaian ketuntasan belajar IPS adalah ratarata nilai pada SMP N 2 Turi adalah 71 dan SMP N 3 Kalasan sebesar 72.

Hasil belajar peserta didik yang rendah tidak dapat sepenuhnya menyalahkan peserta didik karena hasil belajarnya yang kurang baik.
Ada banyak faktor yang mempengaruhi baik buruknya hasil belajar yang diperoleh peserta didik. Hamalik (1983, p.112) menyatakan bahwa faktor yang mempengaruhi hasil belajar antara lain: (1) faktor yang bersumber dari diri peserta didik, (2) faktor yang bersumber dari lingkungan sekolah, (3) faktor yang bersumber dari lingkungan keluarga peserta didik, (4) faktor yang bersumber dari lingkungan masyarakat. Faktor-faktor yang mempengaruhi hasil belajar dapat dibedakan menjadi dua, yaitu faktor yang berasal dari dalam diri peserta didik (internal) dan faktor yang berasal dari luar diri peserta didik (eksternal). Faktor yang berasal dari dalam diri peserta didik menurut Purwanto (1994, p.5) terbagi menjadi dua yaitu faktor psikologis meliputi intelegensi, motivasi, sikap, dan bakat, kemampuan peserta didik dan Faktor fisiologis meliputi kematangan fisik seseorang. Faktor yang berasal dari luar diri peserta didik meliputi lingkungan sekitar, guru, mata pelajaran, keadaan orang tua, faktor sosial, media pembelajaran, kurikulum, model pembelajaran, sarana dan prasarana, dan lain sebagainya. Salah satu faktor dari luar yang mempengaruhi hasil belajar yakni model pembelajaran.

Peneliti mengeksprimenkan model pembelajaran berbasis masalah dan kooperatif tipe Think Pair Share untuk meningkatkan hasil belajar IPS. Peneliti membandingkan model pembelajaran berbasis masalah dan kooperatif tipe Think Pair Share di dua sekolah yakni di SMP Negeri 2 Turi dan SMP N 3 Kalasan karena kedua model tersebut belum pernah diterapkan di kedua sekolah tersebut. Model berbasis masalah dan kooperatif tipe Think Pair Share mempunyai kelebihan yang dapat meningkatkan hasil belajar. Penelitian yang dilakukan Utami (2015, p. 102), membuktikan bahwa model kooperatif tipe Think Pair Share dapat meningkatkan hasil belajar dan penelitian yang dilakukan Herman (2007, pp.47-56) juga membuktikan model berbasis masalah dapat meningkatkan kemampuan berpikir tingkat tinggi dan hasil belajar peserta didik sekolah menegah pertama.

Pembelajaran berbasis masalah memiliki kelebihan yakni menuntut guru mampu memberikan motivasi dan dorongan kepada peserta didik untuk mengemukakan argumentasi tentang permasalahan sosial yang ada dalam pembelajaran. Pembelajaran berbasis masalah dapat merangsang peserta didik untuk aktif mengamati, menyesuaikan antara teori 
dengan kenyataan, dan dapat mencoba melakukannya sendiri. Pembelajaran berbasis masalah adalah pendekatan pembelajaran peserta didik yang dipadukan dengan masalah autentik, sehingga peserta didik dapat menyusun pengetahuan sendiri, menumbuhkan ketrampilan dan inquiri, memandirikan peserta didik, dan dapat meningkatkan kepercayaan diri sendiri. Ngalimun (2012, p.90) mengemukakan bahwa model pembelajaran berbasis adalah suatu model pembelajaran yang melibatkan peserta didik untuk memecahkan masalahmasalah. Berns \& Erickson (2001, p.2) menyatakan bahwa problem based teaching and learning is a conception of teaching and learning that helps teachers relate subject matter content to real world situations, and motivates students to make connections between knowledge and its applications to their lives as family members, citizens, and workers and engage in the hard work that learning requires. Model pembelajaran berbasis masalah merupakan suatu model pembelajaran yang melibatkan peserta didik untuk memecahkan masalah-masalah secara nyata.

Masalah-masalah secara nyata bisa berasal dari pengalaman diri sendiri maupun pengalaman dari lingkungan peserta didik. Pengalaman yang berasal dari diri sendiri misalnya konflik dengan teman, sedangkan pengalaman dari lingkungan peserta didik misalnya pertikaian antar warga. Barge (2010, p.7) mengatakan tentang masalah yang digunakan dalam pembelajaran berbasis masalah yakni a problem can be theoritical, practical, social, technical, symbolic-cultural and/or scientific and grows out of students' wondering within different diciplines and professional enviroments. The problem is the starting point directing the students' learning process and situates the learning in a context. Suatu masalah dapat berupa teori, praktis, masyarakat, teknik, simbol budaya atau pembelajaran nyata dan tumbuh pada diri peserta didik dalam berbagai displin dan lingkungan yang baik. Permasalahan merupakan langkah awal untuk peserta didik melakukan proses pembelajaran dan belajar menghadapi situasi pembelajaran yang sesuai dengan konteks peserta didik. Peserta didik dilatih untuk belajar bagaimana menyelesaikan masalah, sehingga peserta didik akan terbiasa dan mampu memecahkan permasalahan apapun. Pemecahan masalah-masalah sosial melalui tahap-tahap metode ilmiah sehingga peserta didik tidak hanya mempelajari konsepkonsep yang berhubungan dengan masalah tetapi juga metode ilmiah untuk memecahkan masalah tersebut.

Model pembelajaran lainnya yang dapat digunakan yaitu model pembelajaran kooperatif tipe Think Pair Share. Pembelajaran kooperatif tipe Think Pair Share menghargai peserta didik untuk berpikir secara individual, berinteraksi dengan pasangannya dan membagikan informasi keseluruh peserta didik dan guru di kelas. Azlina (2010, p.22) mengemukakan bahwa pembelajaran kooperatif tipe Think Pair Share membuat peserta didik saling menghargai, berpikir secara individual, berinteraksi dengan pasangannya dan membagikan informasi kepada seluruh peserta didik dan guru di kelas. Pembelajaran menggunakan Think Pair Share menurut Sugiarto \& Sumarsono (2014, p.209) melalui 5 langkah antara lain peserta didik mengorganisasikan untuk berpasangan. Model Think Pair Share diawali dengan membagi peserta didik untuk berpasangan secara acak, peserta didik menyampaikan topik atau pertanyaan, guru memberikan waktu kepada peserta didik untuk berpikir dan menjawab pertanyaan yang diberikan sebelumnya, guru menyampaikan kepada peserta didik untuk mendiskusikan bersama pasangannya dan menyampaikan hasil pemikirannya, guru memanggil atau mengumpulkan beberapa peserta didik untuk menyampaikan pendapatnya di depan kelas.

Pembelajaran kooperatif tipe Think Pair Share membantu peserta didik untuk meningkatkan pengetahuan dari berbagi informasi, ide, dan ketrampilan. Berangkat dari uraian diatas maka peneliti mencoba meneliti tentang "Pengaruh model pembelajaran berbasis masalah dan kooperatif tipe Think Pair Share terhadap hasil belajar IPS di SMP N 2 Turi dan SMP N 3 Kalasan.

\section{Metode Penelitian}

Jenis Penelitian

Penelitian ini menggunakan pendekat-an kualitatif dengan metode eksperimen. Bentuk desain eksperimen yang digunakan dalam penelitian ini adalah matched subjects design. Hadi (2015, p.244) mengatakan bahwa matched subjects designs yaitu eksprimen yang menggunakan kelompok eksprimen dan kelompok kontrol yang sudah disamakan subjek 
demi subjek sebelum eksprimen. Subjek yang disamakan adalah satu variabel atau lebih yang telah diketahui mempunyai pengaruh terhadap hasil eksprimen. Matched subjects designs dijalankan berlandaskan pada adanya matched subjects pada dua kelompok yang dipersiapkan untuk eksperimen. Matched subjects yang dijodohkan tiap-tiap subyek pada kelompok yang satu dengan subyek pada kelompok yang lain. Hasil kemampuan awal peserta didik di SMP N 2 Turi dan SMP N 3 Kalasan diasumsikan sama karena diketahui mempunyai pengaruh terhadap hasil belajar.

Waktu dan Tempat Penelitian

Waktu penelitian dilakukan bulan MaretApril 2015 pada semester genap tahun ajaran 2014/2015. Tempat penelitian dilakukan di SMP N 2 Turi dan SMP N 3 Kalasan di Kabupaten Sleman Yogyakarta.

Populasi dan Sampel Penelitian

Populasi pada penelitian ini adalah peserta didik kelas VIII di SMP N 2 Turi dan SMP N 3 Kalasan, Sleman pada semester kedua tahun ajaran 2014/2015 yang masing-masing sekolah baik SMP N 2 Turi dan SMP N 3 Kalasan berjumlah 128 peserta didik yang terdiri dari VIII A, VIII B, VIII C, VIII D. Sampel adalah bagian dari jumlah dan karakteristik yang dimiliki oleh populasi tersebut. Pemilihan sampel pada penelitian ini dipilih dengan menggunakan teknik random sampling. Sampel dipilih secara acak/random, dan diperoleh hasil kelas VIII C SMP N 2 Turi menggunakan model kooperatif tipe Think Pair Share dan kelas VIII B SMP N 3 Kalasan menggunakan model pembelajaran berbasis masalah.

Prosedur

Rancangan penelitian yang digunakan adalah matched subjects designs dijalankan berlandaskan pada adanya matched subjects pada dua kelompok yang dipersiapkan untuk eksperimen. Matched subjects yang dijodohkan tiap-tiap subyek pada kelompok yang satu dengan subyek pada kelompok yang lain. Hasil kemampuan awal peserta didik di SMP N 2 Turi dan SMP N 3 Kalasan diasumsikan sama karena diketahui mempunyai pengaruh terhadap hasil belajar. Peserta didik diberi tes kemampuan awal pada kelas berbasis masalah dan kelas Think Pair Share untuk mengukur rerata kompetensi pengetahuan sebelum objek diberi perlakuan. Peserta didik kemudian diberikan perlakuan model pembelajaran berbasis masalah di SMP N 3 kalasan dan model Think Pair Share di SMP N 2 Turi. Peserta didik diberikan post test setelah mendapat perlakuan berbasis masalah dan Think Pair Share untuk mengukur rerata hasil belajar untuk kompetensi pengetahuan, penilaian diri untuk mengukur kompetensi sikap dan lembar pengamatan untuk mengukur kompetensi ketrampilan.

Data, Intrumen, dan Teknik Pengumpulan Data

Data penelitian ini dikumpulkan menggunakan instrumen berupa tes uraian berbentuk analisis kasus terdiri dari lima pertanyaan yang digunakan untuk mengukur kemampuan awal peserta didik. Tujuan tes kemampuan awal untuk mengetahui skor kemampuan awal peserta didik sebelum mengikuti pembelajaran model berbasis masalah dan model kooperatif tipe Think Pair Share. Tes ini digunakan untuk menilai hasil belajar peserta didik yang mencakup tiga aspek yaitu aspek pengetahuan, sikap dan keterampilan. Teknik pengumpulan data dalam penelitian ini dilakukan dengan dua teknik, yaitu teknik tes dan non tes. Teknik tes digunakan tes uraian berbentuk analisis kasus. Teknik non tes berupa penilaian diri dan penilaian keterampilan. Hasil belajar aspek pengetahuan menggunakan tes uraian berbentuk analisis kasus terdiri dari lima pertanyaan. Perhitungan hasil belajar peserta didik ini akan digunakan sebagai penentuan perbedaan hasil belajar peserta didik yang dipengaruhi oleh penerapan model pembelajaran berbasis masalah dan model kooperatif tipe Think Pair Share yang dikontrol oleh kemampuan awal peserta didik. Materi yang akan diajarkan saat penelitian ini adalah tema tentang konflik sosial. Penilaian sikap menggunakan lembar penilaian diri yang berupa daftar cek atau skala penilaian. Penilaian diri merupakan teknik penilaian untuk meminta peserta didik mengemukakan kelebihan dan kekurangan dirinya dalam konteks pencapaian aspek sikap sosial maupun spritual. Penilaian aspek ketrampilan menggunakan lembar pengamatan diskusi dan presentasi. Penilaian aspek ketrampilan digunan untuk mengetahui ketrampilan peserta didik saat mengikuti pembelajaran. 
Teknik Analisis Data

Teknik analisis Analisis data pada penelitian ini terdiri dari dua yaitu analisis deskriptif dan analisis inferensial. Analisis deskriptif dilakukan dengan menyajikan data melalui tabel frekuensi, mean. Analisis inferensial pada penelitian ini menggunakan Paired sample $t$ test. Paired sample $t$ test merupakan analisis dengan melibatkan dua pengukuran pada subjek yang sama terhadap suatu pengaruh atau perlakuan tertentu. Pengujian sampel pada penelitian ini dilakukan sebanyak dua kali dengan sampel yang sama yakni tes kemampuan awal dan post test (setelah diberi perlakuan). Uji prasyarat dilakukan sebelum uji hipotesis. Uji prasyarat terdiri dari pengujian hipotesis dengan uji normalitas menggunakan Kolmogorof Smirnov (K-S). Uji normalitas digunakan untuk mengetahui apakah sampel yang digunakan untuk penelitian ini berasal dari populasi yang berdistribusi normal atau tidak. Uji homogenitas menggunakan uji Levene's Test. Uji homogenitas dimaksudkan untuk mengetahui apakah sampel berasal dari populasi yang homogen.

\section{Validitas dan Reliabilitas Data}

Validitas instrumen dibagi menjadi validitas logis, berkaitan dengan validitas isi (content validity) dan validitas konstruk (construct validity) divalidasi oleh ahli (expert judgement). Validitas empiris dilakukan dengan uji coba instrumen pada penilaian aspek pengetahuan, sikap dan ketrampilan. Validitas instrumen penilaian sikap dan ketrampilan dianalisis menggunakan rumus korelasi Pearson Product moment. Hasil perhitungan instrumen sikap terbuka, rasa ingin tahu, sikap berpikir kritis menggunakan SPSS dapat diketahui bahwa dari lima item sikap terbuka (t) yakni t5 $\mathrm{r}$ hitung $0,320<\mathrm{r}$ tabel 0,349 gugur karena $r$ hitung $<r$ tabel. Sikap rasa ingin tahu (r) yang jumlahnya lima item yakni item r4 gugur karena $\mathrm{r}$ hitung $0,278<\mathrm{r}$ tabel 0,349 . Instrumen sikap berpikir kritis menggunakan SPSS dapat diketahui bahwa sikap berpikir kritis (k) yang jumlahnya lima item, instrumen sikap spritual yang berjumlah empat item dan instrumen aspek ketrampilan yang berjumlah tujuh item, aspek pengetahuan dan kemampuan awal yang berjumlah lima item dikatakan valid karena $\mathrm{r}$ hitung $>\mathrm{r}$ tabel dengan signifikansi $5 \%$.
Reliabilitas keseluruhan tes kemampuan awal, tes hasil belajar aspek pengetahuan, sikap dan ketrampilan dapat diperoleh dengan menggunakan koefisien Alpha Cronbach. Perhitungan instrumen sikap terbuka mempunyai koefisien reliabilitas sebesar 0,734 $>0,60$, artinya reliabilitas untuk instrumen kompetensi sikap adalah tinggi, instrumen sikap rasa ingin tahu mempunyai koefisien reliabilitas sebesar $0,601>0,60$, artinya reliabilitas untuk instrumen kompetensi sikap rasa ingin tahu adalah sedang, instrumen sikap berpikir kritis mempunyai koefisien reliabilitas sebesar 0,644 $>0,60$, artinya reliabilitas untuk instrumen kompetensi sikap berpikir kritis adalah tinggi, sedang instrumen sikap spritual mempunyai koefisien reliabilitas $0,754>0,60$, artinya reliabilitas untuk instrumen kompetensi sikap spritual adalah tinggi, instrumen keterampilan diskusi mempunyai koefisien reliabilitas sebesar $0,608>0,60$, artinya reliabilitas untuk instrumen kompetensi ketrampilan diskusi adalah tinggi, instrumen keterampilan presentasi mempunyai koefisien reliabilitas sebesar $0,604>0,60$, artinya reliabilitas untuk instrumen kompetensi ketrampilan adalah tinggi, dan instrumen pengetahuan mempunyai koefisien reliabilitas sebesar $0,766>0,60$, artinya reliabilitas untuk instrumen kompetensi pengetahuan adalah tinggi. Instrumen kemampuan awal mempunyai koefisien reliabilitas sebesar $0,516>0,60$, artinya reliabilitas untuk instrumen kemampuan awal adalah sedang. Reliabiltas instrumen pengetahuan, sikap, dan keterampilan dan kemampuan awal adalah reliabel.

\section{Hasil Penelitian dan Pembahasan}

Hasil belajar pada penelitian ini dilihat dari kompetensi pengetahuan, sikap, dan ketrampilan. Menurut Suprijono (2011, p.5) bahwa hasil belajar merupakan pola-pola perbuatan, nilai-nilai, pengertian-pengertian, sikap-sikap, apresiasi, dan keterampilan, sehingga hasil belajar harus mencakup pengetahuan, sikap, dan ketrampilan. Ranah afektif berkaitan dengan ranah sikap peserta didik. Jacobsen (2009, p.92) mengatakan tentang ranah afektif, yang berkaitan dengan tingkah laku, perasaan, nilai. Ranah psikomotorik mengembangkan kekuatan otot dan koordinasi merupakan fungsi utama tujuantujuan dalam ranah psikomitor. Ranah pengetahuan berkaitan dengan intelektual 
peserta didik. Menurut Sudjana (2010, pp. 2223) ada tiga klasifikasi taksonomi belajar yaitu: Ranah kognitif, berkenaan dengan hasil belajar inteletual yang terdiri atas enam aspek, yaitu pengetahuan atau ingatan, pemahaman, aplikasi, analisis, sintesis dan evaluasi. Ranah afektif, berkenaan dengan hasil belajar sikap yang terdiri dari lima aspek yaitu pemahaman, aplikasi, analisis, sintesis, dan evaluasi. Ranah psikomotoris, berkenaan dengan hasil belajar ketrampilan serta kemampuan bertindak.

Hasil analisis statistik diskriptif dapat diketahui bahwa skor kemampuan awal nilai rata-rata sebesar 73, 63 di SMP N 3 Kalasan dan nilai rata-rata sebesar 73, 63 di SMP N 2 Turi, artinya kemampuan awal di kedua sekolah masih dibawah standar KKM yakni 75. Data dapat dilihat pada Tabel 1. Berikut

Tabel 1. Skor Kemampuan Awal Pembelajaran di SMP N 2 Turi dan SMP N 3

Kalasan

\begin{tabular}{clc}
\hline No. & \multicolumn{1}{c}{ Kelompok } & Skor \\
\hline & & \\
Mean 1 & SMP N 2 Turi & 73,63 \\
Mean 2 & SMP N 3 Kalasan & 73,63 \\
\hline
\end{tabular}

Pada tabel diatas menggambarkan bahwa kemampuan awal di kedua sekolah tersebut masih rendah. Kemampuan awal sebagai titik tolak guru untuk menentukan model pembelajaran yang digunakan saat pembelajaran sehingga nantinya dapat menjembatani pengetahuan yang telah dimiliki peserta didik dengan pengetahuan yang baru sesuai dengan kemampuan peserta didik. Winkel (1991, p.80) menyatakan bahwa kemampuan awal merupakan jembatan untuk menuju pada kemampuan final. Setiap proses belajar mengajar mempunyai titik-tolaknya sendiri atau berpangkal pada kemampuan peserta didik tertentu untuk dikembangkan menjadi kemampuan baru, seperti apa yang menjadi tujuan dalam proses pembelajaran, ini berarti pengalaman belajar yang lalu memegang peranan untuk memahami konsep-konsep baru. Kemampuan awal peserta didik akan berpengaruh pada proses pembelajaran. Kemampuan awal peserta didik merupakan pengetahuan yang telah dimiliki peserta didik untuk mengikuti proses pembelajaran yang dihadapi peserta didik. Oleh karena iu, untuk mengatasi hal tersebut maka di SMP N 2 Turi peneliti memberi perlakuan model kooperatif tipe Think Pair Share dan di
SMP N 3 Kalasan diberi perlakuan model pembelajaran berbasis masalah. Kedua model tersebut diharapkan dapat meningkatkan hasil belajar baik di SMP N 2 Turi maupun di SMP N 3 Kalasan.

Sasaran penilaian hasil belajar peserta didik terhadap aspek pengetahuan meliputi mengetahui, menerapkan, menganalisis, mengevaluasi pengetahuan faktual, pengetahuan koseptual, pengetahuan procedural. Penilaian kemampuan berpikir berbagai tingkat pengetahuan dinyatakan dalam predikat berdasarkan skor rerata. plikasi, analisis, sintesis dan evaluasi.

Hasil posttest aspek pengetahuan penelitian ini menujukkan hasil posttest lebih tinggi model pembelajaran berbasis masalah daripada skor posttest model kooperatif tipe Think Pair Share. Pada kelompok model pembelajaran berbasis masalah di peroleh skor rata-rata 83, 81. Kelompok model kooperatif tipe Think Pair Share lebih rendah, yaitu skor skor rata-rata 73, 87. Data dapat dilihat pada Tabel 2. Berikut

Tabel 2. Skor Aspek Pengetahuan Pembelajaran Berbasis Masalah dan TPS

\begin{tabular}{ccc}
\hline No. & Kelompok & Skor \\
\hline & & \\
Mean 1 & Berbasis masalah & 83,81 \\
Mean 2 & TPS & 73,87 \\
\hline
\end{tabular}

Sekala penilaian aspek pengetahuan menggunakan rentang angka dan huruf 4,00 (A) $-1,00$ (D). Skor rerata untuk aspek pengetahuan ditetapkan paling kecil 2, 67. Skor penilaian pada aspek pengetahuan model pembelajaran berbasis masalah di peroleh skor rata-rata 83, 81. Kelompok model kooperatif tipe Think Pair Share lebih rendah, yaitu skor skor rata-rata 73 , 87. Skor aspek pengetahuan baik model pembelajaran berbasis masalah dan kooperatif tipe Think Pair Share telah mencapai kriteria ketuntasan dengan mendapat predikat baik yang mengacu pada Permendikbud nomor 104 tahun 2014.

Ranah belajar sikap terdiri dari lima aspek yaitu pemahaman, aplikasi, analisis, sintesis, dan evaluasi. Sasaran penilaian hasil belajar peserta didik terhadap kompetensi sikap dan spritual meliputi menerima, menanggapi, menghargai, menghayati, dan mengamalkan nilai spritual. Hasil skor aspek sikap kelompok eksprimen model pembelajaran berbasis masalah lebih tinggi dibandingkan pada 
kelompok model kooperatif tipe Think Pair Share. Hal ini ditunjukkan pada hasil skor aspek sikap yang lebih tinggi dengan menggunakan model pembelajaran berbasis masalah dari pada skor aspek sikap model kooperatif tipe Think Pair Share. Pada kelompok eksperimen dengan model pembelajaran berbasis masalah di peroleh skor rata-rata sikap 3, 02. Kelompok eksprimen model kooperatif tipe Think Pair Share lebih rendah, yaitu skor rata-rata 2,87 . Data dapat dilihat pada Tabel 3. Berikut

Tabel 3. Skor Aspek Sikap Pembelajaran Berbasis Masalah dan TPS

\begin{tabular}{ccc}
\hline No. & Kelompok & Skor \\
\hline Mean 1 & Berbasis masalah & 3,02 \\
Mean 2 & TPS & 2,87 \\
\hline
\end{tabular}

Skala penilaian pada aspek sikap baik menggunakan rentang angka dan huruf 4,00 (A) $-1,00$ (D). Skor rerata untuk aspek pengetahuan ditetapkan paling kecil 2,67. Skor aspek sikap pada kelompok eksperimen dengan model pembelajaran berbasis masalah di peroleh skor rata-rata sikap 3, 02. Kelompok eksprimen model kooperatif tipe Think Pair Share lebih rendah, yaitu skor rata-rata 2,87 . Skor aspek ketrampilan pada kelompok berbasis masalah dan kelompok TPS telah mencapai kriteria ketuntasan dengan mendapat predikat baik yang mengacu pada Permendikbud nomor 104 tahun 2014.

Ranah psikomotoris, berkenaan dengan hasil belajar ketrampilan serta kemampuan bertindak. Indikator pencapaian kompetensi keterampilan merupakan ukuran, karakteristik, ciri-ciri, pembuatan atau proses yang berkontribusi serta menunjukkan ketercapaian suatu kompetensi dasar tertentu yang menjadi acuan penilaian mata pelajaran. Penilaian hasil belajar aspek keterampilan meliputi keterampilan mencoba, mengolah, menyaji, dan menalar. Ranah konkret keterampilan mencakup aktivitas meniru, melakukan, menguraikan, merangkai, memodifikasi, dan mencipta. Ranah abstrak keterampilan ini mencakup aktivitas mengamati, menanya, mengumpulkan informasi atau mencoba, menalar atau mengasosiasi, dan mengkomunikasikan.

Hasil ketrampilan pada penelitian ini menunjukkan hasil ketrampilan lebih tinggi dengan menggunakan model pembelajaran berbasis masalah dari pada skor ketrampilan model kooperatif tipe Think Pair Share. Pada kelompok eksperimen dengan model pembelajaran berbasis masalah di peroleh skor skor rata-rata ketrampilan 3, 50. Kelompok eksprimen model kooperatif tipe Think Pair Share lebih rendah, yaitu skor rata-rata 3, 40. Data dapat dilihat pada Tabel 4. Berikut

Tabel 4. Skor Ketrampilan Pembelajaran Berbasis Masalah dan TPS

\begin{tabular}{ccc}
\hline No. & Kelompok & Skor \\
\hline & & \\
Mean 1 & Berbasis masalah & 3,50 \\
Mean 2 & TPS & 23,40 \\
\hline
\end{tabular}

Skala penilaian pada ketrampilan kelompok berbasis masalah dan kelompok TPS menggunakan rentang angka dan huruf 4,00 (A) $-1,00$ (D). Skor rerata untuk aspek ketrampilan ditetapkan paling kecil 2,67. Skor aspek ketrampilan pada kelompok eksperimen dengan model pembelajaran berbasis masalah di peroleh skor skor rata-rata ketrampilan 3, 50. Kelompok eksprimen model kooperatif tipe Think Pair Share lebih rendah, yaitu skor ratarata 3, 40. Skor aspek ketrampilan pada kelompok berbasis masalah dan kelompok Think Pair Share telah mencapai kriteria ketuntasan dengan mendapat predikat baik yang mengacu pada Permendikbud nomor 104 tahun 2014.

Hasil uji normalitas pada hasil belajar yang menggunakan model pembelajaran berbasis masalah diperoleh $\mathrm{p}=0,207>0,05$ dan model Think Pair Share diperoleh $\mathrm{p}=0,386>$ 0,05 . Kriteria pengujian yaitu data berasal dari populasi yang berdistribusi normal jika nilai signifikansi probabilitasnya $(p>0,05)$, dan populasi tidak berdistribusi normal apabila $\mathrm{p}<$ signifikansi $\alpha=0,05$, artinya hasil belajar yang menggunakan model berbasis masalah dan model Think Pair Share dinyatakan berdistribusi normal.

Hasil uji homogenitas diperoleh hasil belajar model pembelajaran berbasis masalah dan model kooperatif tipe Think Pair Share bersifat signifikan karena $p=0,309>0,0$. Data dinyatakan homogen jika nilai probabilitas (p) lebih besar dari 0,05 ( $p>0,05)$, kemudian jika nilai $\mathrm{p}$ lebih kecil dari $0,05(\mathrm{p}<0,05)$, maka dinyatakan tidak homogen. Data hasil belajar model pembelajaran berbasis masalah dan model kooperatif tipe Think Pair Share bersifat homogen. 
Prasyarat analisis terpenuhi maka peneliti melanjutkan ke tahap uji hipotesis yakni terdapat perbedaan hasil belajar IPS antara peserta didik yang belajar dengan menggunakan model berbasis masalah dibandingkan yang belajar menggunakan model kooperatif tipe Think Pair Share.

Hasil penelitian ini di dapat bahwa hasil belajar yang menggunakan model pembelajaran berbasis masalah lebih tinggi dibandingkan peserta didik yang belajar menggunakan model kooperatif tipe Think Pair Share. Hal ini sesuai dengan dengan hasil analisis data pada hipotesis, hasil analisis menunjukkan bahwa rerata hasil belajar aspek pengetahuan dengan menggunakan model berbasis masalah lebih tinggi daripada rerata kelompok model TPS. Data dapat dilihat pada Tabel 5. Berikut

Tabel 5. Hasil Belajar Peserta didik

\begin{tabular}{llrlr}
\hline \multicolumn{5}{c}{ Paired Samples Statistics } \\
\hline & & Rata-rata & N & \multicolumn{1}{c}{ Std. Deviasi } \\
\hline Pair 1 & MS & 83,19 & 32 & 4,596 \\
& TPS & 73,88 & 32 & 6,719 \\
\hline
\end{tabular}

Hasil belajar dengan menggunakan model berbasis masalah sebesar 83, 19 lebih tinggi dibandingkan dengan model Think Pair Share sebesar 73, 88. Hasil uji t dapat dilihat pada tabel 6. Berikut.

Tabel 6. Hasil uji t

\begin{tabular}{|c|c|c|c|c|c|c|}
\hline & \multicolumn{4}{|c|}{ Paired Differences } \\
\hline & & & Mean & $\mathrm{T}$ & Df & $\begin{array}{l}\text { Sig. (2- } \\
\text { tailed) }\end{array}$ \\
\hline $\begin{array}{l}\text { Pair } \\
1\end{array}$ & $\begin{array}{l}\text { MS } \\
\text { TPS }\end{array}$ & - & 9,312 & 15,189 & 31 &, 000 \\
\hline
\end{tabular}

Pada tabel diatas dapat diketahui bahwa $\mathrm{T}$ hitung 15,189 $>\mathrm{T}$ tabel 2, 042 pada taraf signifikansi 0,05 . T hitung $>\mathrm{T}$ tabel maka Ho ditolak dan Ha diterima. Hasil 1 uji korelasi juga menunjukkan bahwa ada korelasi antara model pembelajaran berbasis masalah dan kooperatif tipe Think Pair Share sebesar 0,878 dengan sig sebesar 0,000 , artinya terdapat perbedaan hasil belajar IPS antara peserta didik yang belajar dengan menggunakan model berbasis masalah dibandingkan yang menggunakan model kooperatif tipe Think Pair Share.
Salah satu permasalahan yang umum muncul dalam pembelajaran IPS di sekolah adalah belum optimalnya hasil belajar Peserta didik. Ada beberapa faktor yang mempengaruhi baik buruknya hasil belajar peserta didik. Faktor dapat berasal dari dalam diri maupun dari luar diri peserta didik. Angkowo \& Kosasih (2007, p.51) menyatakan bahwa hasil belajar peserta didik dipengaruhi oleh lima faktor yaitu: (1) bakat belajar peserta didik, (2) waktu yang tersedia untuk belajar, (3) kemampuan setiap peserta didik, (4) kualitas mengajar guru, (5) lingkungan peserta didik. Hasil belajar peserta didik di sekolah $70 \%$ dipengaruhi oleh kemampuan peserta didik dan $30 \%$ dipengaruhi oleh lingkungan. Faktor yang mempenaruhi hasil belajar menurut Purwanto (1994, p.5) terbagi menjadi dua yaitu faktor dari dalam yang terdiri dari psikologis meliputi intelegensi, motivasi, sikap, dan bakat, kemampuan peserta didik dan Faktor fisiologis meliputi kematangan fisik seseorang. Faktor yang berasal dari luar diri peserta didik meliputi lingkungan sekitar, guru, mata pelajaran, keadaan orang tua, faktor sosial, media pembelajaran, kurikulum, model pembelajaran, sarana dan prasarana, dan lain sebagainya. Faktor dari luar yang mempengaruhi hasil belajar yakni model pembelajaran.Pemilihan model pembelajaran yang tepat akan mempengaruhi suasana belajar peserta didik yang menyenangkan sehingga mempengaruhi hasil belajar.

Berbeda dengan kenyataan yang ada di lapangan bahwa belum semua pembelajaran IPS dilakukan dengan model pembelajaran yang bervariasi, serta pemilihan model pembelajaran yang kurang memperhatikan kemampuan awal peserta didik sehingga membuat peserta didik kurang terstimulasi untuk mengembangkan pengetahuan peserta didik. Model pembelajaran berbasis masalah dan Think Pair Share (TPS) menunjukkan hasil yang signifikan. Hal ini sesuai dengan dengan hasil analisis data pada hipotesis, hasil analisis menunjukkan bahwa rerata hasil belajar dengan menggunakan model berbasis masalah sebesar 83, 19 lebih tinggi daripada rerata kelompok model TPS 73, 88. Hasil analisis data menunjukkan bahwa terdapat perbedaan hasil belajar IPS antara peserta didik yang belajar dengan menggunakan model berbasis masalah dibandingkan yang menggunakan model kooperatif tipe Think Pair Share terlihat pada T hitung 15,189 > T tabel 2, 042 . 
Ngalimun (2012, p.90) mengemukakan bahwa pembelajaran berbasis masalah adalah suatu pembelajaran yang melibatkan peserta didik u model pembelajaran berbasis masalah merupakan model yang menghadapkan peserta didik pada suatu permasalahan yang nyata, dengan maksud agar peserta didik dapat menyusun sendiri pengetahuan yang dimilikinya. Tujuan utama dari model pembelajaran berbasis masalah adalah untuk mengembangkan kemampuan berfikir peserta didik, sehingga mereka mampu memecahkan masalah yang tengah dihadapi. Konteks model pembelajaran berbasis masalah antara lain: mempresentasikan permasalahan/ kasus yang dibahas, mendiskusikan permasalahan/kasus dan mengembangkan sesuai dengan kenyataan yang ada, pembelajaran mandiri yang terfokus pada objek yang dibahas, dan mendiskusikan, mencari ide-ide baru dan mencari solusi di dalam kelompok. Peran seorang guru dalam pembelajaran berbasis masalah hanya sebagai pembimbing dan fasilitator. Pembelajaran berbasis masalah sosial dapat merangsang peserta didik untuk aktif mengamati, menyesuaikan antara teori dengan kenyataan, dan dapat mencoba melakukannya sendiri pemahaman materi yang diterima peserta didik akan melekat kuat dalam diri peserta didik sehingga hasil belajarnya pun dapat meningkat secara optimal dibandingkan dengan model kooperatif tipe Think Pair Share (TPS).

Model TPS merupakan salah satu bentuk pengembangan dari model diskusi yang penerapannya melalui tiga tahap/prosedur yaitu berfikir, berpasangan dan berbagi. Lie (2004, p.57) mengemukakan bahwa pembelajaran tipe Think Pair Share merupakan salah satu model pembelajaran kooperatif yang memberikan kesempatan kepada peserta didik untuk bekerja sendiri serta bekerja dengan orang lain. Model pembelajaran Think Pair Share dapat meningkatkan kemampuan komunikasi peserta didik karena peserta didik harus saling menyampaikan hasil pemikiran masing-masing dan saling berdiskusi dengan pasangannya. Jumlah anggota kelompok yang kecil mendorong setiap anggota untuk terlibat secara aktif.

Model pembelajaraan kooperatif tipe Think Pair Share dapat meningkatkan partisipasi anggota kelompok dan memberikan kesempatan untuk berkontibusi masing-masing anggota kelompok. Pembelajaran Think Pair Share membimbing peserta didik untuk memiliki tanggung jawab dalam kelompok atau pasangannya. Model pembelajaran kooperatif tipe Think Pair Share membuat peserta didik aktif dalam mengembangkan kemampuan diri peserta didik, mengembangkan kemampuan berkelompoknya serta ketrampilan sosial.

Hipotesis menyatakan bahwa: terdapat perbedaan hasil belajar IPS antara peserta didik yang belajar dengan menggunakan model berbasis masalah lebih tinggi dibandingkan yang menggunakan model kooperatif TPS dapat diterima. Hasil belajar IPS antara peserta didik yang belajar dengan menggunakan model berbasis masalah lebih tinggi dibandingkan yang menggunakan model kooperatif TPS, artinya memberikan model berbasis masalah memberikan pengaruh yang lebih baik dibandingkan model kooperatif tipe Think Pair Share.

Penelitian ini membuktikan bahwa hasil belajar IPS antara peserta didik yang belajar dengan menggunakan model berbasis masalah lebih baik dibandingkan yang menggunakan model kooperatif tipe Think Pair Share. Hasil belajar yang menggunakan model pembelajaran berbasis masalah lebih tinggi dibandingkan dengan yang menggunakan model kooperatif tipe Think Pair Share. Penelitian ini sama dengan penelitian yang di ungkapkan oleh utami (2015, p.102) bahwa model PBL dan TPS sama-sama mempunyai pengaruh terhadap hasil belajar IPS. Hal ini ditunjukkan dengan hasil analisis yang menunjukkan nilai probabilitas sebesar $0,000<\operatorname{sig} 0,05$. Namun yang membedakan penelitian ini dengan penelitian sebelumnya bahwa pada penelitian ini membuktikan bahwa model pembelajaran berbasis masalah lebih baik dibandingkan dengan model TPS. Berbeda dengan penelitian sebelumnya yang membuktikan bahwa hasil belajar siswa dengan penerapan metode PBL diperoleh rata-rata sebesar 65,50 sedangkan hasil belajar siswa dengan penerapan metode TPS diperoleh ratarata sebesar 76, 37 .

\section{Simpulan dan Saran}

\section{Simpulan}

Simpulan penelitian ini adalah terdapat perbedaan hasil belajar IPS antara peserta didik yang belajar dengan model pembelajaran berbasis masalah. Rerata hasil belajar kelompok berbasis masalah sebesar 83, 19 lebih tinggi dibandingkan rerata kelompok model kooperatif tipe Think Pair Share (TPS) 73, 88. Hasil uji 
hipotesis pada peningkatan hasil belajar antara peserta didik yang menggunakan model pembelajaran berbasis masalah dan kooperatif tipe TPS diperoleh T hitung 15, $189>\mathrm{T}$ tabel 2, 042 pada taraf signifikansi 0,05 , artinya terdapat perbedaan hasil belajar IPS antara peserta didik yang menggunakan model pembelajaran berbasis masalah dan model TPS. Hasil belajar IPS yang menggunakan model pembelajaran berbasis masalah lebih tinggi dibandingkan model TPS, artinya model berbasis masalah memberikan pengaruh yang lebih baik dibandingkan model TPS.

Saran

Teori dan hasil-hasil penelitian yang telah teruji kebenarannya mengatakan bahwa penerapan model pembelajaran yang tepat dapat meningkatkan hasil belajar belajar peserta didik secara optimal. Penelitian ini telah membuktikan bahwa model pembelajaran dapat mempengaruhi hasil belajar, artinya bahwa model pembelajaran menjadi salah satu faktor yang mempengaruhi hasil belajar. Guru sebaiknya menggunakan model pembelajaran berbasis masalah dan model kooperatif tipe Think Pair Share karena terbukti dapat meningkatkan hasil belajar IPS. Model pembelajaran berbasis masalah merupakan sutau model pembelajaran dimana peserta didik menghubungkan materi pelajaran dengan kehidupan sehari-hari. Model pembelajaran berbasis masalah mengajarkan bagaimana peserta didik berpikir secara kritis, melatih peserta didik berpikir terbuka, menuumbuhkan rasa ingin tahu terhadap masalah-masalah sosial yang terjadi di masyarakat. Model kooperatif tipe Think Pair Share (TPS) juga digunakan pada penelitian ini. Penerapan model pembelajaran berbasis masalah dan model kooperatif tipe TPS membuat peserta didik menjadi aktif dan dapat menumbuhkan kerjasama, berpikir kritis, terbuka, rasa ingin tahu sehingga model kooperatif tipe TPS dapat meningkatkan hasil belajarnya secara signifikan. Hasil penelitian ini menyimpulkan bahwa model pembelajaran berbasis masalah dan model pembelajaran kooperatif tipe TPS berpengaruh terhadap hasil belajar IPS peserta didik. Model pembelajaran berbasis masalah memberikan pengaruh yang lebih baik dibandingkan dengan model pembelajaran kooperatif tipe TPS. Oleh karena itu peneliti menyarankan guru sebaiknya menerapkan model pembelajaran berbasis masalah dan model kooperatif tipe Think Pair Share (TPS) yang terbukti dapat meningkatkan hasil belajar dalam melaksanakan pembelajaran IPS, selain itu perlu adanya penelitian lebih lanjut untuk mengetahui apakah pembelajaran berbasis masalah dan model kooperatif tipe Think Pair Share dapat diterapkan dan memberi hasil yang efektif terhadap hasil belajar baik pada mata pelajaran IPS atau mata pelajaran lain dengan materi yang berbeda.

\section{Daftar Pustaka}

Angkowo \& Kosasih. (2007). Optimalisasi media pembelajaran. Jakarta: PT Grasindo.

Azlina, N.A.N. (2010). Supporting collaborative activities among students and teachers through the use of think pair share techniques. International Journal of Computer Science, 7, 18-29.

Barge, S., (2010). Principles of problem and project based learning. Aalborg University: Harvad university.

Berns dan Erickson, S. (2003). Learning theories. An Educational Perspective. 2nd ed. Englewood Cliffs, NJ: Merrill/Prentice-Hall.

Hadi, Sutrisno (2015). Statistik. Yogyakarta: Pustaka Pelajar.

Jacobsen, D.A. (2009). Method for teaching: promoting student learning in $k-12$ classrooms. (Terjemahan Achmad Fawaid \& Khoirul Anam). USA: Upper Saddle River. (Buku asli diterbitkan tahun 2009).

Lie, Anita. (2004). Cooperative learning: mempraktekkan cooperative learning di ruang-ruang kelas. Jakarta: PT. Grasindo.

Murdaningsih, Dwi. (22 April 2015). USAID terapkan pelatihan model pembelajaran. Republika, hlm.13.

Ngalimun. (2012). Strategi dan model pembelajaran. Yogyakarta: Pressindo.

Permendikbud Nomor 104 Tahun 2014, tentang proses penilaian hasil belajar oleh 
pendidik pada pendidikan dasar dan menengah.

Purwanto, Ngalim. (1994). Prinsip-prinsip dan teknik evaluasi pengajaran. Bandung: PT Remaja Rosdakarya.

Sugiarto, D. \& Sumarsono, P. (2014). The implementation of think-pair-share model to improve students ability in reading narrative texts. International Journal of English and Education, 3, 206-215.

Sudjana, Nana. (2010). Penilaian hasil proses belajar mengajar. Bandung: PT Remaja Rosdakarya.

Suprijono, Agus. (2011). Cooperative learning: teori dan aplikasi paikem. Yogyakarta: Pustaka Pelajar.

Trianto. (2010). Model pembelajaran terpadu: konsep, strategi, dan implementasinya dalam kurikulum tingkat satuan pendidikan. Jakarta : Bumi Aksara.

Undang-Undang No. 14 Tahun 2005 tentang Guru dan Dosen.

United Nations Development Programme. (2014). Human development index trends 1980-2013. New York: U.S. Human Development Report Office.

Utami, P., Gafur, A..Pengaruh metode pembelajaran dan gaya belajar siswa terhadap hasil belajar ips di smp negeri di kota yogyakarta. Harmoni Sosial: Jurnal Pendidikan IPS, North America, 2, mar. 2015.

Winkel, W.S. (1991). Psikologi pengajaran. Jakarta: Grasindo.

\section{Profil Singkat}

Dina Anika Marhayani, lahir di Sleman, Yogyakarta pada tanggal 14 Juni 1989. Melalui pendidikan jenjang sarjana program studi Pendidikan Ilmu Pengetahuan Sosial Universitas Negeri Yogyakarta dan lulus pada tahun 2012. Pengalaman dalam pekerjaan antara lain sebagai guru di SD Muhammadiyah Dadapan (2012 - 2013), kemudian melanjutkan jenjang magister program studi Pendidikan Ilmu Pengetahuan Sosial konsentrasi Pendidikan IPS Terpadu di Universitas Negeri Yogyakarta tahun 2013.

Hastuti, lahir pada tanggal 27 Juni 1962. Melalui pendidikan jenjang sarjana program studi geografi Universitas Gajah Mada Yogyakarta dan lulus pada tahun 1986. Jenjang magister program studi geografi Universitas Gajah Mada Yogyakarta dan lulus pada tahun 1994. Jenjang Doktor program studi geografi Universitas Gajah Mada Yogyakarta dan lulus pada tahun 2009. Sekarang menjabat sebagai dosen geografi di Universitas Negeri Yogyakarta. 